\title{
Deflation and Stock Prices
}

\author{
Michael Clemens \\ BankInvest Group, Copenhagen, Denmark
}

\begin{abstract}
While the literature on inflation and stock prices is plentiful, there is little literature on deflation and stock prices. This paper explores the empirical data and makes a theoretical analysis of the likely impact on stock prices when expectations change from inflation to deflation. Deflation has a bad name among some economists and most investors. However, from a stock market perspective, deflations' bad name may not be well-deserved. Several observations support this: 1) The 1930s was a statistical outlier and not representative for a deflationary period and deflation does not seem to create recessions, causality goes the other way; 2) real stock returns are positive and around average in the periods leading up to and following the onset of deflation; 3) when moving from low inflation to mild deflation, P/E ratios are virtually unchanged; and 4) peak P/E ratios seem to be reached at inflation rates close to zero. The author proposes three possible explanations for the seemingly disconnect between the empirical data and the "default" ex ante belief of most economists and investors: availability heurist, deflation illusion, and tax related issues in connection with the tax hypothesis.
\end{abstract}

Keywords: deflation, stock prices, price-to-earnings ratio, availability heuristic, deflation illusion, tax hypothesis

\section{Introduction}

The literature on inflation and stock prices is vast. However, studies of how deflation impacts stock prices are scarce; perhaps because the Western world has not seen much deflation since the Great Depression in the 1930s. In Japan, the economy has been on-off moderate deflation since the mid-1990s. The motivation behind this paper is twofold: Firstly, inflation is currently (mid-2017) running at low levels and it probably takes another period of recession before deflation becomes a real risk. Secondly, there is (almost) a vacuum in the empirical and theoretical literature regarding deflation and stock prices. Figure 1 illustrates the disinflation tendency in the US, Germany, and Switzerland in recent decades and the on-off deflation tendency in Japan in the last 20 years.

In order to qualify as a deflationary period, there is general agreement that the decline in prices must be broad-based and sustained over a longer period. Bernanke (2002) defined deflation as: "Deflation per se occurs only when price declines are so widespread that broad-based indexes of prices, such as the consumer price index, register ongoing declines" (p. 2).

Deflation is often divided into good and bad deflation (Bordo, Lane, \& Redish, 2004; Beckworth, 2007). Good deflation typically follows a positive supply shock, while bad deflation typically follows a negative

Michael Clemens, M.Sc. (Econ.), chief portfolio manager, BankInvest Group, Copenhagen, Denmark.

Correspondence concerning this article should be addressed to Michael Clemens, BankInvest Group, Sundkrogsgade 7 , Copenhagen DK-2100, Denmark. 
demand shock. The fear of deflation, also called apoplithorismosphobia ${ }^{1}$, stems from the possible consequences of bad deflation.

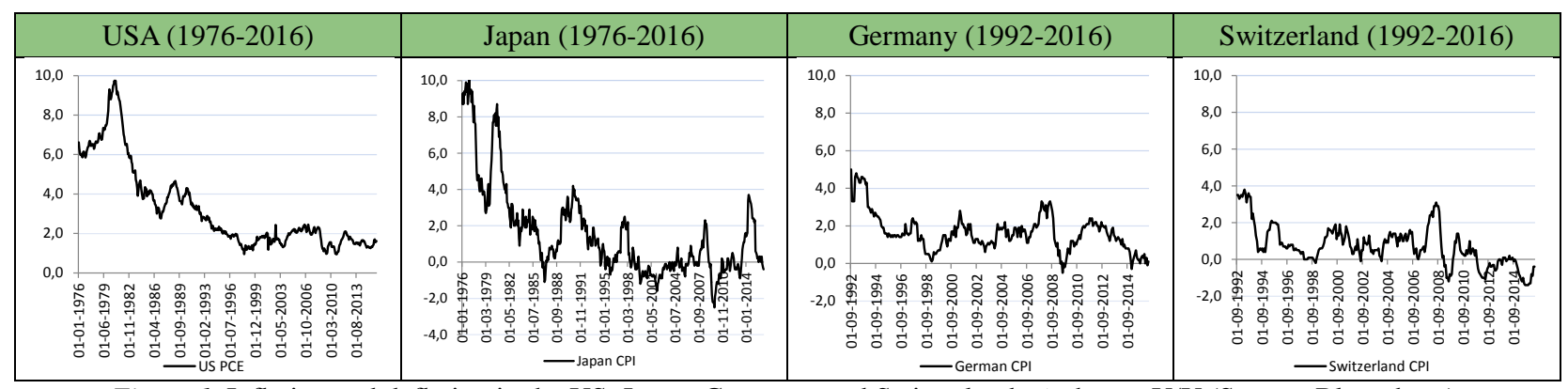

Figure 1. Inflation and deflation in the US, Japan, Germany, and Switzerland, \% change Y/Y (Source: Bloomberg).

Note. Starting dates differ due to different data availability for each country.

Table 1

Theoretical Consequences of Bad Deflation

\begin{tabular}{l}
\hline Households defer consumption of (discretionary) goods and services in expectation of lower prices in the future \\
\hline Firms reduce investments in face of lower demand \\
\hline Higher unemployment, especially if nominal wages are rigid to the downside \\
\hline Nominal interest rates reach zero lower bound ${ }^{2}$ \\
\hline Unplanned increase in real cost of debt and potentially decreases in collateral values ${ }^{3}$ \\
Reduced interest margin and increased loan losses in the banking sector reduce the efficiency of financial intermediation \\
\hline Lower tax revenues to the government \\
Notes. The list is not meant to be exhaustive, only illustrative. Sources: DeLong (1999), Thornton (2003), Morana (2005), \\
Beckworth (2007), and Eichengreen (2015).
\end{tabular}

If these consequences and complications reinforce each other, collectively they may lead to a negative (bad) deflation spiral, which most academics believe should be avoided at (more or less) all costs ${ }^{4}$. This begs important questions: Are these consequences real, i.e., supported by empirical data? Are they just outcomes of theoretical economic models? What are the possible implications, if any, on stock prices?

For example, on rigid nominal wages, Kuroda and Yamamoto (2014, p. 154) concluded from the Japanese experience that downward rigidity in nominal wages was present until 1998, after which it disappeared and that wage cuts were commonplace during the 2000s. The experience from Sweden during the 1921-1923 deflation period also suggests that wages were downward flexible however, with a lag of around one year (Fregert \& Jonung, 2004). Most recent experience with rigid nominal wages in the West has occurred during inflationary periods and may therefore not be a relevant reference point in periods of deflation. Regarding real economic

\footnotetext{
1 Thornton (2003) defined apoplithorismosphobia (ay-pope-lit-horris-mos-foe-be-ah) as the fear of deflation or more precisely the fear that the economy will suffer from falling prices. Apparently, the word is Greek in origin.

2 The problem with zero lower bound nominal interest rates stem primarily from the issue of physical money (paper notes and coins) as opposed to other money supply (electronic). The zero interest rate applied to physical money in theory acts as a floor for policy rates and deposit rates, although costs of storing and protecting large amounts of physical money in practice reduces the zero lower bound below zero.

3 A decrease in collateral values (houses and stocks) is not necessarily a consequence of deflation, but perhaps more the causing factor of an economic slowdown, which then causes deflation.

4 There are "dissidents" to this view, most prominently Friedman (1969) who argues for a zero nominal interest rate, which implies that prices must decline at the real rate of interest. Friedman argues that the opportunity cost of holding money should equal the costs of creating new money. Since the marginal cost of creating new money is close to zero, nominal interest rates should be zero.
} 
growth, empirical evidence suggests that mild and transitory deflation do not harm economic growth much, if at all (see later). Morana (2005) suggested that the deflation shock must be larger than what Japan has experienced since the mid-1990s in order to have a significant negative effect on the real economy. On the zero-lower-bound issue, recent experience with negative interest rates which until a few years ago were unthinkable suggests that this issue, while still relevant to some degree, is not as big a problem, as theory suggests.

Anyhow, the way the economy (consumers, firms, and government) and investors react to deflation may have profound implications on stock prices and stock valuation.

The main finding and contribution of this paper are that deflation as such is not necessarily bad for stock returns and valuation. Actually, based on historical data, peak P/E ratios are found at close to zero inflation, and in many cases, stock returns and $\mathrm{P} / \mathrm{E}$ ratios under periods of mild deflation are equally attractive as under periods of low inflation. The author proposes three possible explanations for the seemingly disconnect between the empirical data and the "default" ex ante belief of most economists and investors: availability heurist, deflation illusion, and tax related issues in connection with the tax hypothesis.

The rest of this paper is organized by five parts: Firstly, a literature review is conducted of how inflation/deflation impacts stock prices, stock returns, and stock valuation. Secondly, empirical data for the US are investigated to find historical relationships between stock valuation (price-to-earnings) and inflation. The data used are provided by Professor Robert Shiller's database. Various robustness checks are performed with data provided by Bloomberg. Thirdly, a simple theoretical exercise is conducted using the Gordon growth model to model impacts on share prices and valuation rations as expectations change from inflation to deflation with possible implications for nominal and real interest rates as nominal and real economic growth and risk premiums. Fourth, US forward P/E data from Datastream/Bloomberg are extrapolated from inflation territory into deflation territory. Section five sums of the evidence from Sections three and four and provides possible explanations for the findings. A conclusion summarizes the main findings.

\section{Literature Review}

On the one side, there is a vast literature on inflation and stock prices. On the other side, there is very little literature on deflation and stock prices. Smith (2006), in his review of the empirical evidence on deflation, observed “... there are many gaps in our empirical work on deflation" (p. 1043). That fact has not changed since then. A quick non-scientific search (May 2018) on Google Scholar reveals around 1,600,000 hits on "inflation" and around 47,000 hits on "deflation" since 2006. Narrowing it down to include also the words "stock prices", there are around 154,000 hits on "inflation stock prices" but only around 17,900 hits on "deflation stock prices". This paper hopes to narrow the research gap on deflation just a bit.

The literature on inflation and stock prices may be categorized into (at least) four broad hypotheses:

- The hypothesis of inflation illusion ${ }^{5}$, advocated by among others Modigliani and Cohn (1979), Ritter and Warr (2002), Campbell and Vuolteenaho (2004), Cohen, Polk, and Vuolteenaho (2005), and Brown, Huang, and Wang (2016).

\footnotetext{
${ }^{5}$ Inflation illusion is the hypothesis that suggests investors discount real cash flows with nominal discount rates and ignore the decline in the real value of nominal debt in the presence of (high) inflation.
} 
- The proxy hypothesis ${ }^{6}$ which focuses on the spill-over effects of high inflation to reduced real economic activity (Fama, 1981).

- The hypothesis that inflation increases the general risk aversion and hence equity risk premia, as suggested by Brandt and Wang (2003). Kyriacou, Madsen, and Mase (2006) and Madsen and Dzhumashev (2009) also suggested that inflation drives up the equity risk premium.

- The tax hypothesis which focuses on taxes and the adverse impacts of inflation, including Nichols (1968), Motley (1969), Feldstein (1980), and Summers (1981). Within the tax hypothesis, it is important to distinguish between the adverse impact of inflation due to the set-up of the corporate tax system (depreciation allowances based on historical costs increase the real tax burden in times of high inflation), and the adverse impact due to investor taxes (taxation of nominal gains reduces real return after taxes).

Unfortunately, most of the literature on inflation and stock prices does not consider whether the effects on stock prices of inflation and disinflation may be extrapolated into deflation territory. Instead, most deflation literature focuses on how deflation impacts monetary policy, economic growth, interest rates, etc. Whenever the stock market is mentioned, it is often as a part of a broader discussion of asset price deflation, as a contributing factor to recession and/or deflation, rather than as a consequence of deflation (Borio, Erdem, Filardo, \& Hofmann, 2015) for example.

Only a few papers deal with the stock market and deflation. Madsen and Milas (2005) found a non-linear relationship between the price-dividend ratio and inflation/deflation. In times of deflation, management is reluctant to lower dividends per share in line with deflation, possible due to an expected adverse impact on the share price when (nominal) dividends per share are lowered. Hence, the dividend pay-out ratio increases. Conversely, in times of high inflation, the dividend pay-out ratio falls as management is reluctant to raise dividend per share in line with inflation due to the difficulties of predicting high inflation. While Madsen and Milas (2005) provided a behavioural explanation, this pattern fits very well with the trend in real profits of companies, which, ceteris paribus, increase in times of low inflation/deflation compared to times of high inflation (Feldstein, 1980). Madsen (2002) found a positive relation between the equity risk premium and inflation in the post-war period, and a negative relation during the Great Depression years in the 1930s. Since inflation is positive in the post-war period, this suggests that the equity risk premium increases as inflation rise, and since the Great Depression mostly saw deflation, it also suggests that the equity risk premium rises as deflation worsens. Hence, a U-shaped relation between inflation/deflation and the equity risk premium is likely. Ahmed and Cardinale (2005) explored nominal and real equity returns under different inflation regimes in the US, UK, German, and Japan over a 76 to 93 year period ending in 2003. Interestingly, they found that real returns in periods of deflation do not differ markedly (averaged over all four countries) from equity returns in periods of low inflation (between $0 \%$ and $1.5 \%$ p.a.) and that real returns were the lowest in periods of high inflation. Their results are close to those reported for the USA in Figure 2.

In an experimental setting, Noussair, Richter, and Tyran (2012) found that real asset prices quickly adapted to inflationary shocks but reacted much slower to deflationary shocks. Nominal loss aversion and the disposition effect may be responsible for this asymmetric response to nominal shocks. Fehr and Tyran (2001) found similar results but suggested that an asymmetrical money illusion effect is behind the results.

\footnotetext{
${ }^{6}$ Balduzzi (1995) found very little support for the Proxy Hypothesis in his "new look at the data" for the period 1954-1990. On the other hand, Kim (2003) found support for the proxy hypothesis using quarterly data for Germany over the period 1970-1999. Madsen (2002) investigated various versions of the proxy hypothesis.
} 
In a theoretical model, Bhamra, Dorion, Jeanneret, and Weber (2017) investigated the impact on equity prices in deflation and inflation states of the economy. In their model, deflation reduces real equity prices, while inflation increases real equity prices. The transmission mechanism is a non-linear response to the equity risk premium as default risk increases more in a deflation state of the economy than it decreases in an inflation state, when the nominal debt is fixed. Using monthly returns regressed on changes in the producer price index, they find support for their model in the empirical data.

Summing up, the existing literature on deflation and stock prices reveals that little research exists on the subject. The literature that does exist confirms the stickiness of dividends also in times of high inflation and/or deflation. Perhaps surprisingly, one study shows real equity returns in periods of deflation of more or less same size as real returns under low inflation. One explanation might be asymmetrical price responses to positive and negative nominal shocks.

\section{Empirical Data for the US}

Data for the US are sourced from the database maintained by Professor Robert J. Shiller ${ }^{7}$.

\begin{tabular}{|c|c|c|c|c|}
\hline $\begin{array}{l}\text { Inflation Regime } \\
\text { Level of inflation }\end{array}$ & $\begin{array}{l}\text { Deep Deflation } \\
\text { Below }-3 \% \text { p.a. }\end{array}$ & $\begin{array}{l}\text { Mild Deflation } \\
-3 \% \text { to } 0 \% \text { p.a. }\end{array}$ & $\begin{array}{c}\text { Low Inflation } \\
0 \% \text { to }+5 \% \text { p.a. }\end{array}$ & $\begin{array}{c}\text { High Inflation } \\
\text { Above }+5 \% \text { p.a. }\end{array}$ \\
\hline \multicolumn{5}{|l|}{ Description of data } \\
\hline No. Of months & 231 & 166 & 948 & 360 \\
\hline Average Inflation, $\%$ p.a. & $-7.1 \%$ & $-1.3 \%$ & $2.4 \%$ & $9.5 \%$ \\
\hline \multicolumn{5}{|l|}{ Valuation } \\
\hline Average $P / E, x$ & 14.5 & 15.5 & 16.9 & 10.4 \\
\hline$P / E$ Index & 85 & 91 & 100 & 61 \\
\hline Dividend Yield, \% & $5.6 \%$ & $4.5 \%$ & $3.5 \%$ & $5.3 \%$ \\
\hline DY Index & 162 & 130 & 100 & 152 \\
\hline Dividend Payout Ratio, \% & $81 \%$ & $70 \%$ & $59 \%$ & $55 \%$ \\
\hline Payout Index & 139 & 119 & 100 & 93 \\
\hline \multicolumn{5}{|l|}{ Nominal Total Return } \\
\hline Last 12 months & $4.8 \%$ & $20.5 \%$ & $12.1 \%$ & $6.5 \%$ \\
\hline Next 12 months & $6.6 \%$ & $10.0 \%$ & $11.3 \%$ & $11.3 \%$ \\
\hline \multicolumn{5}{|l|}{ Real Total Return } \\
\hline Last 12 months & $11.0 \%$ & $21.9 \%$ & $9.4 \%$ & $-1.5 \%$ \\
\hline Next 12 months & $8.3 \%$ & $8.4 \%$ & $8.9 \%$ & $7.5 \%$ \\
\hline
\end{tabular}

Figure 2. P/E ratios, dividend yield, pay-out ratios and stock returns during different inflationary regimes in the US (1872-2016). Source: Shiller database and own calculations. Notes. (1) The inflation/deflation boundaries chosen, while not arbitrary, are not scientifically grounded either. However, the results in the table are robust to smaller changes (+/-1\% point) in the inflation/deflation boundaries; (2) Average P/E is calculated as the average of three P/E metrics: the Shiller Cyclically adjusted Price-Earnings Ratio (CAPE), an own defined last 12 months P/E (based on Shiller data), and an own defined next 12 months P/E (assuming perfect foresight, based also on Shiller data); (3) Dividend yield is calculated as the average of the last 12 months dividend divided by the share price and the next 12 months dividend (assuming perfect foresight) dividend by the share price; (4) The dividend pay-out ratio is calculated as the inverse of the average P/E ratio (E/P) divided by the dividend yield; (5) Returns are calculated from 12 months before the onset of deflation/inflation (last 12 months) and from 12 months after the onset of deflation/inflation (next 12 months); (6) The relative ranking of real returns does not change much if instead last six months and next six months returns were used. Periods with high inflation still show the lowest real returns, while real returns in periods up to and after the onset of deflation are still on par with returns during low inflation periods.

\footnotetext{
${ }^{7}$ Link to database: http://www.econ.yale.edu/ shiller/data.htm.
} 
For the purpose of this paper, deflation is defined when the average of the last 12 months annual change in the Consumer Price Index (CPI) is negative. This definition should capture the broad-based (CPI), ongoing (12 months average), and decline (negative) deflation criteria listed by Bernanke (2002).

Figure 2 shows the average P/E ratio, dividend yield, and pay-out ratio for the US over the period (January) 1872 to (February) 2016 depending on the inflation regime.

From Figure 2, it is clear that P/E ratios are the highest in periods of low inflation (defined as "normal", index $=100$ ), and that $\mathrm{P} / \mathrm{E}$ ratios suffer much more in periods of high inflation compared to periods of deflation. Cohn and Lessard (1981) also found a negative relation between P/E and inflation. In periods of mild deflation, $\mathrm{P} / \mathrm{E}$ ratios suffer $9 \%$ compared to "normal". Dividend yield and pay-out ratios are the highest in periods of deflation, supporting the claim of Madsen and Milas (2005). Periods that lead up to mild deflation have the highest nominal and real returns. However, returns are most stable before and during periods of low inflation. Interestingly, real price returns are actually higher in periods of mild and severe deflation compared to periods of high inflation. Madsen (2002) found almost similar results in his international survey of real returns when comparing the period 1927-1937 (+7.0\% real return, nine countries) to the1962-1999 period $(+6.0 \%$ real return, 16 countries).

\section{Best-Fit Analysis}

A scatter plot is well suited to arrive at a "best-fit" function for the relationship between P/E ratios and inflation.

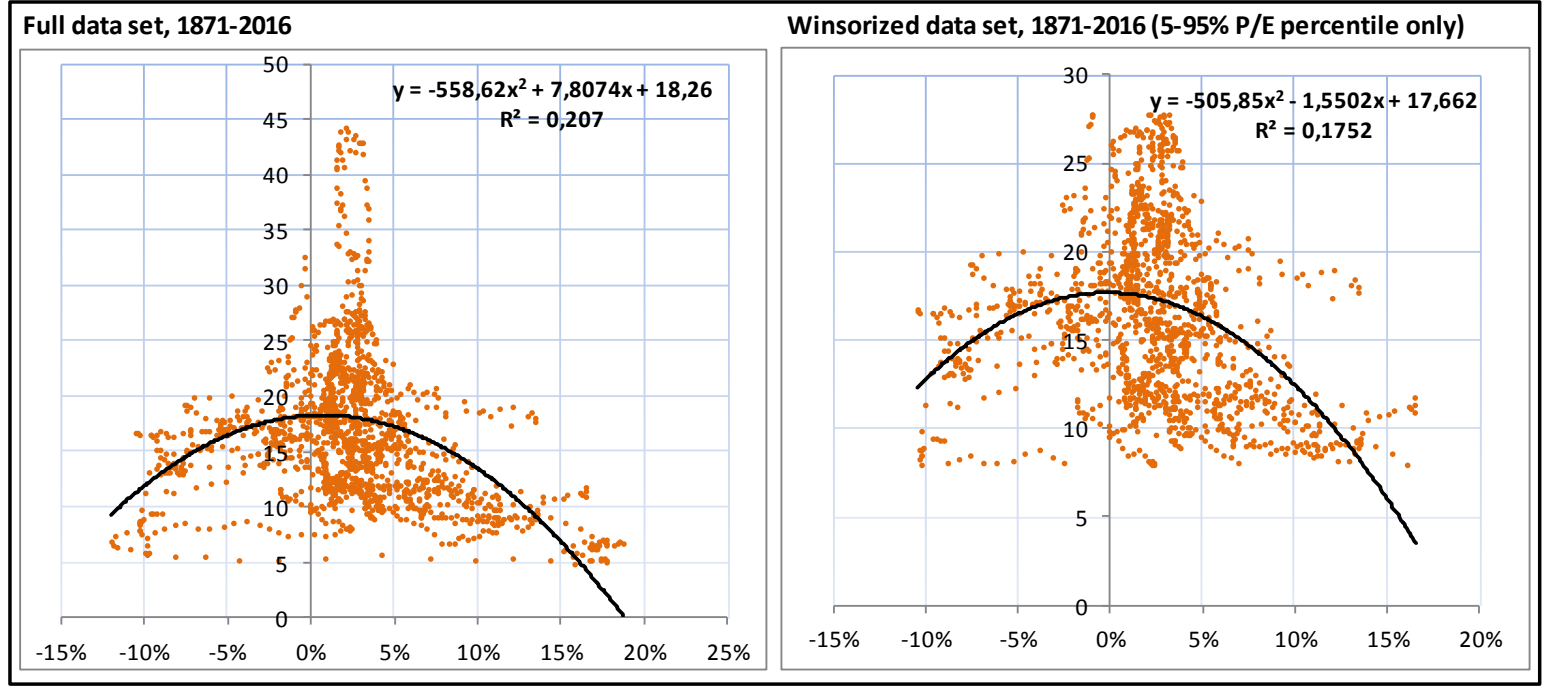

Figure 3. Best-fit function for P/E inflation in the US (1874-2016).

The best-fit function turns out to be a negative power-function in both the full dataset and in the winsorized dataset. R-squares are acceptable at around 0.18-0.21. Perhaps more interestingly however, is that maximum $\mathrm{P} / \mathrm{E}$ ratios of $18.3 \mathrm{x}$ and $17.7 \mathrm{x}$ is reached at $+0.7 \%$ inflation and $-0.2 \%$ deflation, respectively.

\section{Robustness Check}

To check the robustness of the conclusions above, the US data will be analysed for different sub-periods and data for Switzerland and Japan for more recent years will be analysed. Due to a much shorter data history, data for Switzerland and Japan have just been divided into deflation (below zero) and inflation (above zero). 
Dividing the US time series into an early period (1872-1951) and a late period (1952-2016) suggests that the relationship between inflation/deflation and $\mathrm{P} / \mathrm{E}$ is quite robust over time.

From Figure 4, we can conclude that absolute P/E ratios in the US during mild deflation do not differ markedly from the early period to the late period. Interestingly, in the early period, P/E ratios during times of mild deflation were higher than $\mathrm{P} / \mathrm{E}$ ratios during times of low inflation. $\mathrm{P} / \mathrm{E}$ ratios during times of high inflation are the lowest in both the early and the late period. Unfortunately (from a statistical standpoint), there are no periods of deep deflation in the late period. High or low P/E ratios are reflected, more or less, in low and high dividend yields.

Both Japan and Switzerland have experienced periods of (mild) deflation in recent years. Japan has been on-off deflation since the mid-1990s, while Switzerland's experience is more recent.

\begin{tabular}{|l|rrrr|}
\hline $\begin{array}{l}\text { Inflation Regime } \\
\text { Level of inflation }\end{array}$ & $\begin{array}{c}\text { Deep Deflation } \\
\text { Below }-3 \% \text { p.a. }\end{array}$ & $\begin{array}{c}\text { Mild Deflation } \\
-3 \% \text { to }\end{array}$ 0\% p.a. & $\begin{array}{c}\text { Low Inflation } \\
\text { 0\% to +5\% p.a. }\end{array}$ & $\begin{array}{r}\text { High Inflation } \\
\text { Above }+5 \% \text { p.a. }\end{array}$ \\
\hline P/E, x & & & & \\
Full Period, 1871-2016 & 14.5 & 15.5 & 16.9 & 10.4 \\
Early Period, 1871-1951 & 14.5 & 15.6 & 14.2 & 10.8 \\
Late Period, 1952-2016 & $\mathrm{nmf}$ & 15.0 & 18.8 & 9.9 \\
Dividend Yield, \% & & & & \\
Full Period, 1871-2016 & & & & \\
Early Period, 1871-1951 & $5.6 \%$ & $4.5 \%$ & $3.5 \%$ & $5.3 \%$ \\
Late Period, 1952-2016 & $5.6 \%$ & $4.6 \%$ & $4.9 \%$ & $5.6 \%$ \\
\hline
\end{tabular}

Figure 4. P/E, dividend yield and inflation/deflation in the US (1874-2016). Source: Shiller database and own calculations.

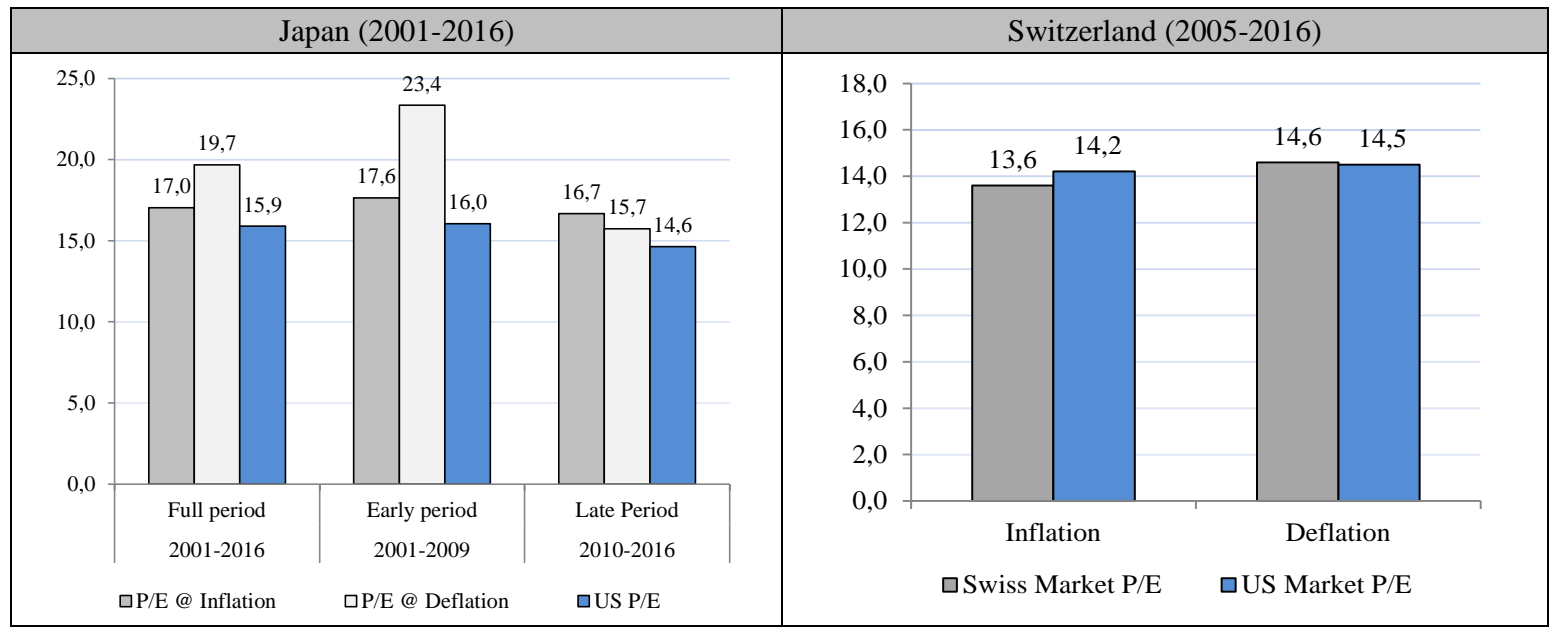

Figure 5. P/E and inflation/deflation for Japan and Switzerland. Source: Bloomberg and own calculations. Notes. (1) $\mathrm{P} / \mathrm{E}$ data used are Bloomberg code BEST_PE_RATIO (estimates for next four quarters) for each country; (2) P/E for Japan is the average of the P/E for the Nikkei 225 and the P/E for the Topix Index; (3). For Switzerland, P/E for the Swiss Market Index (SMI) is used; (4) Periods do not match due to data availability from Bloomberg.

For Switzerland, P/E was higher during periods of deflation compared to periods of inflation, while in Japan during 2010-2016, P/E was the highest during inflationary periods. Interestingly, for both countries, P/E ratios during periods of deflation were higher than in the US, which did not experience deflation during the periods investigated here. ${ }^{8}$ Given internationally integrated capital markets and the internationalization of firms,

\footnotetext{
${ }^{8}$ Lower nominal and real interest rates in Japan and Switzerland compared to the US might explain the higher P/E ratios, as might deflation illusion (see later).
} 
deflation in one country should not have as marked an impact on stock market valuation, as a similar level of inflation say 50 or 100 years ago.

Summing up, the empirical evidence: Over the period from the 1870s to 2016, P/E ratios in the US have not suffered much in periods of deflation compared to periods of low inflation ("normal"). P/E ratios suffer most in periods of high inflation. These patterns are robust over time. Real stock returns are most stable in periods of low inflation. However, the largest returns are found in periods leading up to mild deflation. Even in periods of deep deflation, real returns have been positive and higher than in periods of high inflation, and around the level seen in periods of mild deflation and low inflation.

In more recent years, $\mathrm{P} / \mathrm{E}$ ratios for Japan and Switzerland have been higher during (mildly) deflationary periods than the corresponding $\mathrm{P} / \mathrm{E}$ ratios in the US, which did not see deflation in these periods.

\section{Theoretical Approach}

In order to keep the theoretical analysis simple, the standard Gordons Growth Formula is chosen as a starting point. Initially, the analysis will be done according to text book standards, i.e., without considering (investor) taxes. Hence:

$$
P_{0}=\frac{D P S_{1}}{r_{n}-g_{n}}
$$

where $P_{0}$ is the value of the stock in $t=0, D P S_{l}$ is dividend per share in $t=1, r_{n}$ is nominal cost of equity, and $g_{n}$ is nominal growth in DPS. Re-arranging nominal amounts into real and inflation components and splitting the discount rate into its CAPM-components, the equation will look like:

$$
P_{0}=\frac{D P S_{0} \cdot\left(1+g_{r}+i\right)}{\left(r_{f, r}+i+\beta \cdot r_{p}\right)-\left(g_{r}+i\right)}
$$

where $g_{r}$ is the real growth rate in DPS, $i$ is expected inflation, $r_{f, r}$ is the real risk free rate, $\beta$ is stock beta, and $r_{p}$ is the equity risk premium.

When expectations change from inflation to deflation, possible all components in the nominator and denominator will change.

\section{Real Growth}

The standard textbook assumption is that deflation is bad for real economic growth and therefore also by extension for real dividend growth. However, that may not necessarily be the case. In an international study, Borio et al. (2015) showed that in the post-war period, growth in GDP per capita has actually been higher during periods of mild deflation compared to periods of inflation. ${ }^{9}$ Only during the period 1929-1938, which includes the Great Depression, was there a significant difference between GDP/capita growth in periods of inflation and in periods of deflation. If we look at the whole sample but exclude the period 1914-1947, which still leaves us 117 years ( $82 \%$ of the full sample), the average growth in periods of deflation $(+2.5 \%)$ and inflation $(+2.4 \%)$ is more or less equal. Growth during persistent deflationary periods (five year accumulative drop in consumer prices) is only slightly lower $(+1.9 \%)$.

Borio et al. (2015, p. 42) suggested that periods of negative real GDP growth in association with deflation are more likely caused by a preceding asset price deflation (housing prices and/or stocks prices) and not by the

\footnotetext{
9 Bernstein and Arnott (2003) showed that real EPS follows real GDP per capita more closely than real GDP, as not all GDP growth comes from established companies.
} 
(consumer price) deflation itself: "Once we control for persistent asset price deflations...persistent goods and services (CPI) deflations do not appear to be linked in a statistically significant way with slower growth even in the interwar period" (p. 42). This view is supported by among others Groth and Westaway (2009). Borio et al. (2015, p. 47) estimated the lost asset values on housing and equities during the financial crisis in 2008-2009 to more than USD 20 trillion. In comparison, a hypothetical three-year deflation of $-1 \%$ p.a. would "only" increase the real value of debt (public and private) by around USD 1 trillion. Hence, the magnitude of the losses suggests that the burden of debt-induced deflation is much smaller than the burden of asset price deflation.

Atkeson and Kehoe (2004) also surveyed international data over the longer term (17 countries and over 100 years of data) and found that, outside of the Great Depression (1929-1934), nearly $90 \%$ of the periods with deflation did not see recessions (65 out of 73 episodes). Splitting the data into pre-1939 and post-1949, they find that real output growth in the post-1949 period was actually higher in years with deflation compared to years with inflation, consistent with Borio et al. (2015).

\begin{tabular}{|c|c|c|c|c|c|c|c|c|}
\hline $\begin{array}{l}\text { Average growth in } \\
\text { GDP/capita, \% p.a. }\end{array}$ & $\begin{array}{r}\text { Full sample } \\
1870-2013 \\
\end{array}$ & $\begin{array}{r}\text { Gold standard } \\
1870-1913 \\
\end{array}$ & $\begin{array}{r}\text { Interwar } \\
1920-1938 \\
\end{array}$ & $1920-28$ & $1929-38$ & $\begin{array}{r}\text { Great Depression } \\
1930-33 \\
\end{array}$ & $\begin{array}{r}\text { Postwar } \\
1947-2013 \\
\end{array}$ & $\begin{array}{r}\text { Average excluding } \\
\text { WW1, 1930's and WW2 } \\
\end{array}$ \\
\hline Deflation & $1,5 \%$ & $1,5 \%$ & $0,5 \%$ & $2,3 \%$ & $-0,8 \%$ & $-2,2 \%$ & $3,2 \%$ & $2,5 \%$ \\
\hline Inflation & $2,7 \%$ & $1,6 \%$ & $3,5 \%$ & $3,5 \%$ & $3,5 \%$ & $0,8 \%$ & $2,7 \%$ & $2,4 \%$ \\
\hline Persistent deflation & $1,0 \%$ & $1,3 \%$ & $0,5 \%$ & $2,8 \%$ & $-1,7 \%$ & $-3,3 \%$ & $2,1 \%$ & $1,9 \%$ \\
\hline Included in Average & & Yes & No & Yes & No & No & Yes & \\
\hline \# of years & 143 & 43 & 18 & 8 & 10 & 3 & 66 & 117 \\
\hline$\%$ of full period & $100 \%$ & $30 \%$ & $13 \%$ & $6 \%$ & $7 \%$ & $2 \%$ & $46 \%$ & $82 \%$ \\
\hline
\end{tabular}

Figure 6. GDP/capita growth over various inflation/deflation regimes. Source: Borio et al. (2015) and own calculations.

Guerro and Parker (2006) studied US data over the period 1780-2003 and found support for the conclusions of Borio et al. (2015) and Atkeson and Kehoe (2004). Capie and Wood (2004) looked at UK data during the 1930s and concluded that neither deflation nor corporate credit spreads transmitted to the real economy as suggested by standard debt-deflation models. Bohl and Siklos (2004) concluded that periods of inflation or deflation cannot explain asset prices and economic performance in Germany in the 1913-1926 period. Guerro and Parker (2006) concluded that recession causes deflation more than the other way around. However, when recession and deflation occur together, the combination might cause lower subsequent growth.

During the period 1994-2015, median annual real GDP growth in Japans has been slightly higher $(+1.5 \%$ $\mathrm{Y} / \mathrm{Y})$ in years with deflation, as compared to years with inflation $(+1.1 \%)$. This fits well with Morana (2005, $\mathrm{p}$. 1349) who surveyed Japan's economic growth and inflation for the period 1995-2003 concluded: "In fact, deflation does not seem to have exercised a significant negative impact on real economic activity" (p. 1349) and suggested that the deflationary pressures may have to be worse than those experienced in Japan, in order to exercise negative influence on the real economic growth.

Benhabib and Spiegel (2009) found an inverted U-shaped relationship between inflation and real growth, with peak growth rates found at moderate levels of inflation. Banerjee and Mehrotra (2018) found a U-shaped relationship between current deflation/inflation and forecast uncertainty, which may have macroeconomic implications.

Smith (2006) argued that the claim that consumers defer spending when facing deflation "... is surely the worst one (argument) made against deflation" (p. 1053). Firstly, a reduced consumption will reduce real interest rates and hence raise investments; and secondly, estimates of the intertemporal elasticity of consumption 
substitution are usually quite low, suggesting a minimal impact from deferred spending.

In summary, empirical evidence does not generally support the theoretical claim that deflation leads to lower real economic growth. Causation usually goes the other way around. Nevertheless, in the theoretical step-by-step valuation approach, lower economic growth will be assumed in the transition from inflation to deflation (causation really not important).

\section{Inflation and Interest Rates}

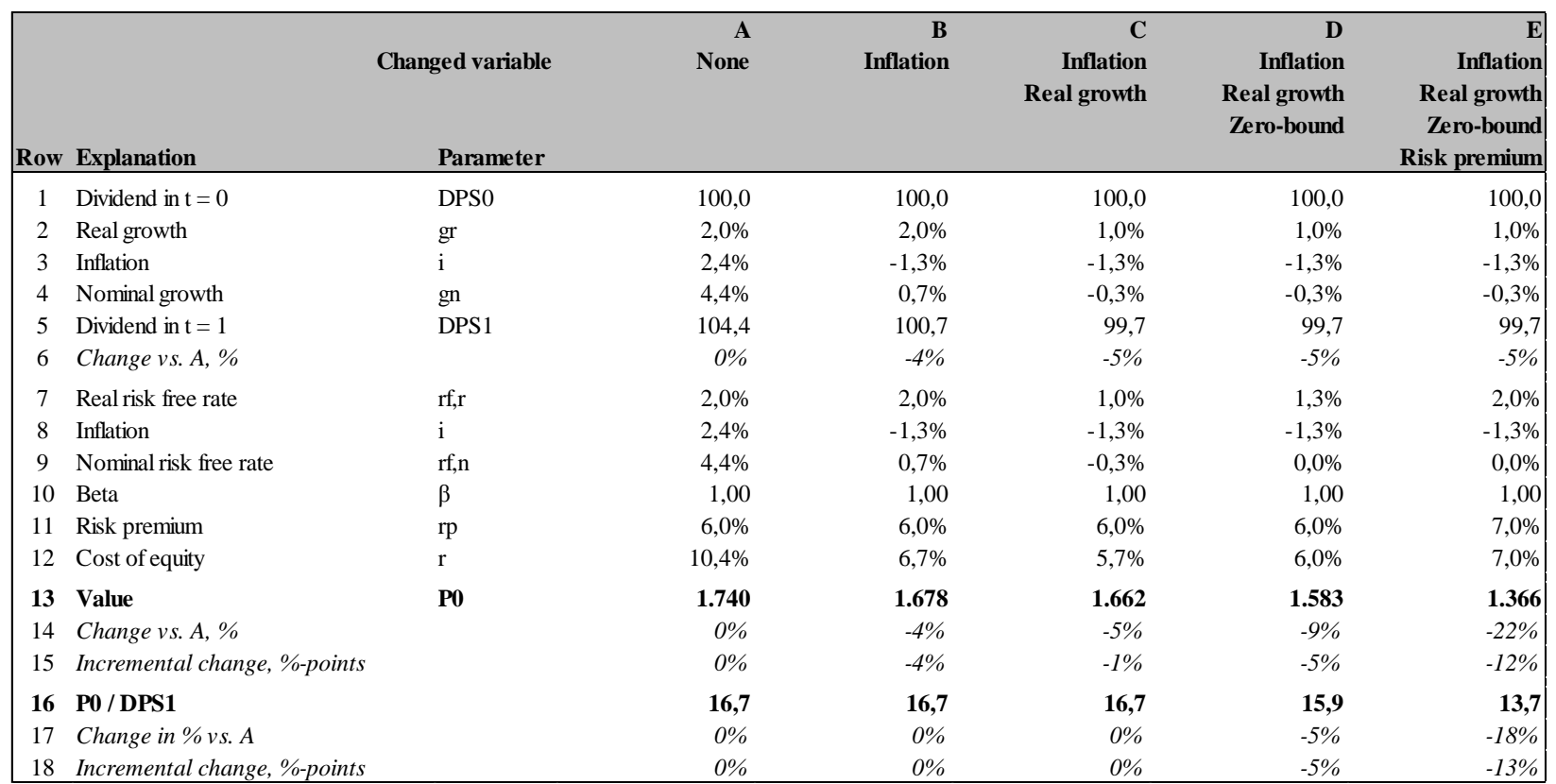

Figure 7. DDM modelling of transition from inflation to deflation I. Notes. (1) To facilitate comparability between the empirical data in Figure 2 and this theoretical example, inflation $(+2.4 \%)$ and deflation $(-1.3 \%)$ expectations are matched to the average inflation rates during "low inflation" and "mild deflation" periods, respectively; (2) The assumption here is a debt free company, which implies that Cost of equity and WACC are the same and that enterprise value equals equity value; (3) Column A represents the base case with expectations of stable "low inflation" (2.4\%). The present value of dividends is 1.740 (Row 13) with a price/dividend ratio of 16.7x (Row 16); (4) In Column B, inflation expectations change (Row 3) as does the expected nominal dividend growth rate (Row 4) and the nominal interest rate (Row 9). The net effect is a 4\% decline in the net present value (Rows 13 and 14), driven by a 4\% lower expected DPS (Rows 5 and 6); (5) In Column C, the real growth rate (Row 2) is assumed to slow given deflation (Row 3 ). This change is also reflected in the real interest rate (Row 7). The net effect is a $5 \%$ lower net present value (Rows 13 and 14), driven entirely by a 5\% lower DPS (Rows 5 and 6). Note Column C does not assume zero-lower-bound nominal interest rates; (6) In Column D, the nominal interest rate is assumed zero lower bound (Row 9), which impacts investors required return (Row 12) through the real interest rate (Row 7). The incremental change in net present value is $-5 \%$ (Row 15) compared to Row $\mathrm{C}$ and in total, the present value is $9 \%$ lower compared to the base case (Column A); (7) In Column E, investors are assumed to increase their required equity risk premium (Row 11). This has a negative incremental influence on the net present value (Row 15) of -12\% compared to Column D. The total value is now $22 \%$ below (Rows 13 and 14) the Base Case (Column A).

In the standard Fisher relation (no investor taxes), the assumption is that a change in inflation expectations will have a similar impact on the nominal interest rate, without any impacts on the real interest rate. In relation to this, if real GDP growth (and hence DPS growth) expectations change from say $+2 \%$ in the inflation scenario to $+1 \%$ in the deflation scenario, the author will assume that the real interest rate changes accordingly (from $+2 \%$ 
to $+1 \%$ ). Glasner (2011) suggested that when the nominal interest rate hits the zero lower bound, the 1:1 relationship between expected inflation and the nominal interest rate in the Fisher relation breaks down. The only way to continue to satisfy the Fisher relation is to increase the real rate of interest. This is exactly what the author has assumed in Scenario D (see Figures 6 and 7).

This is of course a theoretical exercise. Empirical evidence from Japan's two lost decades suggests that inflation expectations barely turned negative (Hori \& Shimizutani, 2005; Nishizaki, Sekine, \& Ueno, 2014). Likewise, Banerjee and Mehrotra (2018) found in an international study that in periods of deflation, inflation expectations did not turn negative.

\section{Risk Premium}

It would not be unexpected if investors will command a higher risk premium (equity and credit) in periods of deflation. Temin (1973, p. 16) mentioned that yields on lower grade bonds began to rise in the beginning of 1930, while yields on higher-grade bonds did not. During that period, short-term policy rates fell sharply, while long-term risk free rates hardly moved. Hence, the move in yield on lower-grade bonds is suggestive of a higher credit spread as the Great Depression unfolded. Leuthold (1981) surveyed US interest rates and inflation over the 1790-1979 period and found that real interest rates are much higher in periods of deflation than in periods of inflation. In fact, there is almost a negative linear relationship between inflation/deflation and real interest rates. With much lower potential real growth in today's US economy than in the 19th century where most of the deflation periods occurred, the question is whether these findings are still relevant today. Davies (2004) found a long-term inverse relationship between corporate credit spreads and the risk free rate (proxy for inflation). Kang and Pflueger (2015) suggested that since corporate bonds are predominantly nominal, firms are therefore exposed to debt deflation. Hence, credit spreads widen when inflation falls unexpectedly. Summing up, the empirical evidence on credit spreads and inflation is mixed and the evidence including periods of deflation is minimal and probably not relevant today.

There are several studies suggesting that the equity risk premium increase with inflation, among others Brandt and Wang (2003), Buraschi and Jiltsov (2005), Kyriacou et al. (2006), Tristani (2007), Beirne and de Bondt (2008), and Madsen and Dzhumashev (2009). Cohen et al. (2005) found that the equity risk premium varies with inflation, indicating that inflation illusion might explain the higher risk premium as inflation rise. This would suggest a lower equity risk premium in times of low inflation/deflation.

Sharpe (2002) found that even if there is an inflation factor in the real required return on stocks, same effect is also found in long-term treasury yields. Hence, expected inflation has little impact on the equity risk premium.

Blanchard (1993, p. 97) estimated (via different regressions) the equity risk premium over the period 1929-1993. For the 1930s, estimates show a sharp rise in the equity risk premium. Hence, in periods of (deep) bad deflation, investors probably require a higher equity risk premium.

Tristani (2007) developed a model of the equity risk premium where "The equity risk premium is increasing in the uncertainty over the distribution of both technology and monetary shocks" (p. 20). A fair assumption would be that monetary uncertainty is at least equally high in times of high inflation and deflation and the lowest in a situation of "price stability" (low inflation).

Summing up, the evidence on the equity risk premium and inflation/deflation is mixed. A general hypothesis about the relationship of the equity risk premium and inflation/deflation is that the equity risk 
premium is increasing as inflation increases and increasing as deflation worsens. Hence, a U-shaped curve with minimum around "price stability" may be a good theoretical starting point.

\section{Theoretical Modelling of Move From Inflation to Deflation}

In order to keep the theoretical analysis simple, the author assumes that the change in inflation/deflation expectations happens instantly. Given the complex relationship between inflation/deflation and valuation, this change may have implications on all parameters in the valuation process.

Figure 7 shows a step-by-step change in the assumptions in a standard Dividend Discount Model as expectations change from inflation to deflation with possible implications for real growth, nominal interest rates, and equity risk premiums.

The lesson to be drawn from this theoretical example is that in a standard text book example, deflation is not that bad, assuming the Fisher relation holds (Columns B and C). However, if nominal interest rates are zero-lower-bound, stock prices may suffer 9\% (Column D). If in addition, investors require a higher risk premium, stock prices fall a total of $22 \%$ (Column E) compared to "normal" (Column A).

While this example is simple and easy to understand, it is not completely correct. The main problem is the lack of consideration of investor taxes, which interacts with inflation to determine the real after-tax required return. Besides, the theoretical contributions from Feldstein (1980) and others, Larry Summers (2014), in his Secular Stagnation speech, also mentioned the interaction between taxes and inflation as an important driver for lower pre-tax real interest rates, as the economy moves from inflation to dis-inflation.

In Figure 8, the discount rate is adjusted for the tax implications of inflation. In the presence of investor taxes, the Fisher relation breaks down as changes in inflation is not passed on one-to-one to the required nominal return. Besides, the changes of investor taxes bring to required nominal returns; assumptions are similar to Figure 7.

\begin{tabular}{|c|c|c|c|c|c|c|}
\hline Row & Changed variables & ${ }^{A}$ None & $\begin{array}{l}\text { B } \\
\text { Inflation }\end{array}$ & $\begin{array}{c}\text { C } \\
\text { Inflation } \\
\text { Real growth }\end{array}$ & $\begin{array}{c}\text { D } \\
\text { Inflation } \\
\text { Real growth } \\
\text { Zero-bound }\end{array}$ & $\begin{array}{c}\mathrm{E} \\
\text { Inflation } \\
\text { Real growth } \\
\text { Zero-bound } \\
\text { Risk premium } \\
\end{array}$ \\
\hline 1 & Cost of equity before investor taxes & $10,4 \%$ & $6,7 \%$ & $5,7 \%$ & $6,0 \%$ & $7,0 \%$ \\
\hline 2 & Inflation & $2,4 \%$ & $-1,3 \%$ & $-1,3 \%$ & $-1,3 \%$ & $-1,3 \%$ \\
\hline 3 & Investor tax rate & $20,0 \%$ & $20,0 \%$ & $20,0 \%$ & $20,0 \%$ & $20,0 \%$ \\
\hline 4 & Tax burden of inflation & $0,5 \%$ & $-0,3 \%$ & $-0,3 \%$ & $-0,3 \%$ & $-0,3 \%$ \\
\hline 5 & Comparable cost of equity after taxes on inflation gains/losses & $10,9 \%$ & $6,4 \%$ & $5,4 \%$ & $5,7 \%$ & $6,7 \%$ \\
\hline 6 & DPS1 & 104,4 & 100,7 & 99,7 & 99,7 & 99,7 \\
\hline 7 & Nominal DPS growth & $4,4 \%$ & $0,7 \%$ & $-0,3 \%$ & $-0,3 \%$ & $-0,3 \%$ \\
\hline 8 & Value & 1.611 & 1.754 & 1.737 & 1.651 & 1.416 \\
\hline 9 & Change vs. A, \% & $0 \%$ & $9 \%$ & $8 \%$ & $2 \%$ & $-12 \%$ \\
\hline 10 & Incremental change, \%-points & $0 \%$ & $9 \%$ & $-1 \%$ & $-5 \%$ & $-15 \%$ \\
\hline 10 & Price / DPS1 & 15,4 & 17,4 & 17,4 & 16,6 & 14,2 \\
\hline 11 & Change vs. A, \% & $0 \%$ & $13 \%$ & $13 \%$ & $7 \%$ & $-8 \%$ \\
\hline 12 & Incremental change, \%-points & $0 \%$ & $13 \%$ & $0 \%$ & $-6 \%$ & $-15 \%$ \\
\hline
\end{tabular}

Comparing Column E in Figures 7 and 8, the change in value from the base case is $-22 \%$ and $-12 \%$, respectively. Hence, investor taxes have a dampening impact on the theoretical stock price fall in the event of 
deflation. Notice that in the "semi-worst-case" (Column D), share prices and P/E ratios actually increase, assuming investor taxes. ${ }^{10}$

Summing up, from a theoretical perspective, it is important to remember that investor's real after tax return increases as inflation falls. Hence, disinflation/deflation is ceteris paribus a good thing for real after tax returns. If the Fisher relation holds, deflation is not that serious for investors. However, if the nominal interest rate is zero-lower-bound, and/or if investors require higher risk premiums, share prices and valuation multiples may suffer.

\section{The Dangerous Extrapolation Exercise}

Basing predictions on statistical extrapolation requires either ignorance or desperation of some sort. However, since deflation has been rare in modern times, extrapolation might be a relevant tool for the answers we are looking for. After all, Ritter and Warr (2002) suggested that reduced inflation illusion account for much of the equity market rally from 1982 to 1999 . By extension then, if inflation expectations continue to be reduced, $\mathrm{P} / \mathrm{E}$ ratios might continue to rise. In this section, the author will use forward looking data from I/B/E/S for the S \& P 500 Index. Data run from January 1979 to June 2016. In Figure 9, scatter plots of the 12 months forward P/E and an estimate of expected inflation ${ }^{11}$, together with a "best-fit" trend line.

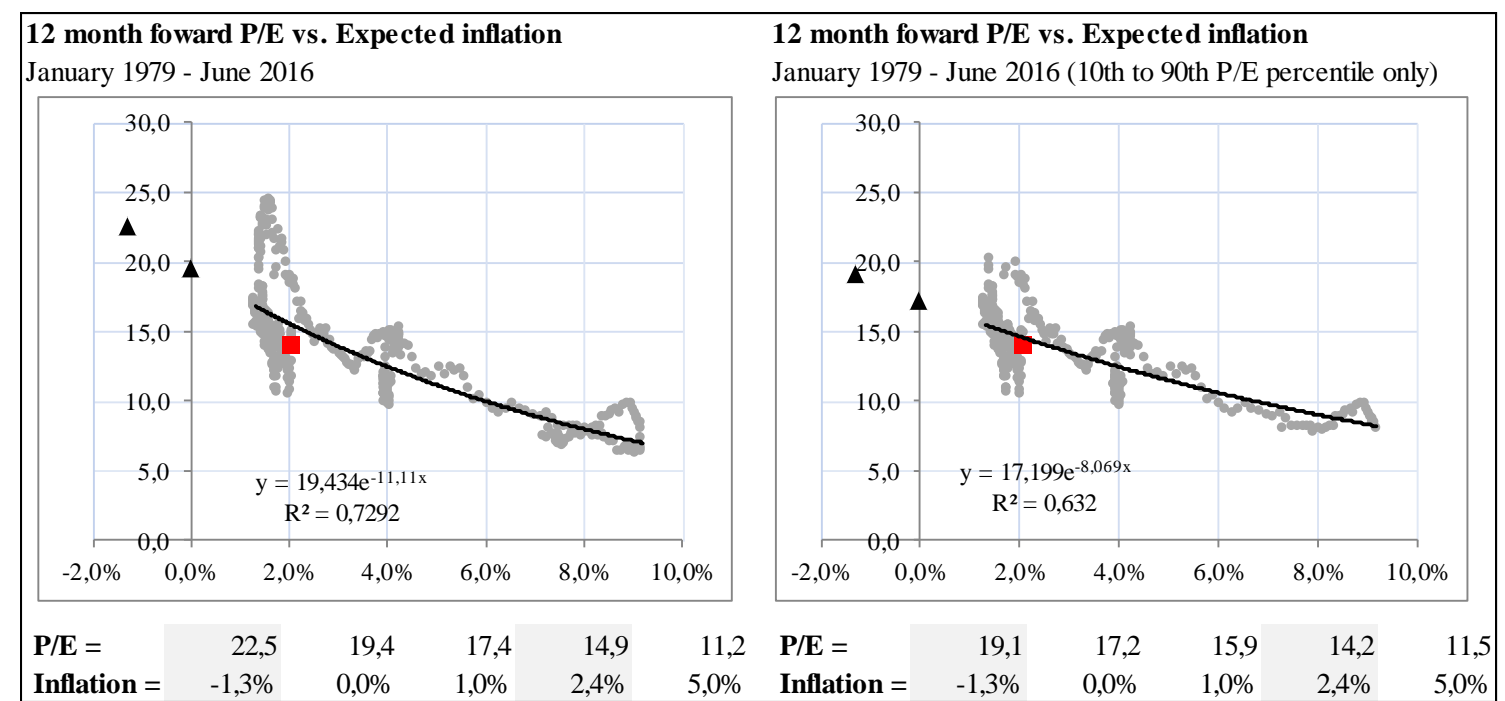

Figure 9. 12 month forward P/E vs. expected inflation, US, 1979-2016. Source: Datastream, I/B/E/S and own calculations. Notes. (1) Black triangles are estimates (extrapolated) based on the best-fit expression; (2) Red squares represent median observation in the data set.

Left chart in Figure 9 uses all data points, while the chart to the right excludes all data outside of 10th and 90th P/E percentiles in an attempt to reduce the impact of possible outliers. Based on the best-fit expressions, $\mathrm{P} / \mathrm{E}$ ratios are estimated in the range of 17-19x given inflation of zero and 19-22x, assuming $1.3 \%$ annual

\footnotetext{
${ }^{10}$ In a real world situation, investors will probably not assume deflation to continue in infinity, but probably assume a few years with deflation (and related issues), followed by a "return to normal". This would probably have a mitigating effect on the drop in present value and $\mathrm{P} / \mathrm{E}$ ratios compared to this "static" example.

${ }^{11}$ I assume adaptive expectations and use the five-year moving average of the PCE deflator as a measure of expected inflation. Regression fit is the highest for this expression of expected inflation. Other version tried were year-over-year increase in PCE, CPI, core CPI and five-year average (expected inflation) increase in core CPI. All had lower R-squared than the five-year average increase in PCE.
} 
deflation. ${ }^{12}$ These are higher estimated P/E levels compared to the historical data from the US (see Figure 3) and the theoretical exercises in Figure 6 and 7.

\section{Possible Explanations}

Figure 10 sums up the evidence from above. Clearly, periods of high inflation stick out with much lower $\mathrm{P} / \mathrm{E}$ ratios than in other periods. The median and average $\mathrm{P} / \mathrm{E}$ ratio is virtually unchanged (actually up 1-2\%) when moving from low inflation into a mild deflation scenario.

\begin{tabular}{|c|c|c|c|c|c|c|c|}
\hline \multirow[t]{2}{*}{ Data source } & \multirow[t]{2}{*}{ Country } & \multirow[t]{2}{*}{ Period } & \multicolumn{2}{|c|}{ Deflation } & \multicolumn{2}{|c|}{ Inflation } & \multirow{2}{*}{$\begin{array}{c}\text { Change, \% } \\
\text { Low Infl. to Mild Defl. }\end{array}$} \\
\hline & & & Severe & Mild & Low & High & \\
\hline \multirow[t]{3}{*}{ Shiller data } & US & $1871-2016$ & 14.5 & 15.5 & 16.9 & 10.4 & $-9 \%$ \\
\hline & US & 1871-1951 & 14.5 & 15.6 & 14.2 & 10.8 & $10 \%$ \\
\hline & US & $1952-2016$ & & 15.0 & 18.8 & 9.9 & $-20 \%$ \\
\hline \multirow[t]{3}{*}{ I/B/E/S } & US & $1979-2016$ & & & 15.2 & 8.2 & \\
\hline & Switzerland & 2005-2016 & & 14.6 & 13.6 & & $7 \%$ \\
\hline & Japan & 2010-2016 & & 15.7 & 16.7 & & $-6 \%$ \\
\hline Theoretical & Without taxes & $\mathrm{nmf}$ & & 13.7 & 16.7 & & $-18 \%$ \\
\hline (Worst Case) & With taxes & $\mathrm{nmf}$ & & 14.2 & 15.4 & & $-8 \%$ \\
\hline \multirow[t]{2}{*}{ Extrapolation } & US, full sample & 1979-2016 & & 22.0 & 14.9 & & $48 \%$ \\
\hline & US, winsorized data & 1979-2016 & & 18.3 & 14.6 & & $25 \%$ \\
\hline Average & & & 14.5 & 16.1 & 15.7 & 9.8 & $2 \%$ \\
\hline Median & & & 14.5 & 15.5 & 15.3 & 10.2 & $1 \%$ \\
\hline
\end{tabular}

Figure 10. Summing up the evidence. Source: Datastream, Shiller database, I/B/E/S and own calculations.

Reading or listening to central bank officials, investment bank strategists, professors in economics and finance, the usual response when deflation is on the agenda is that deflation is very bad for more or less "everything", including the stock market. The author believes that the findings in this paper suggest otherwise and proposes three possible explanations for the seemingly divergence between ex ante beliefs among professionals and ex post data: availability heuristic, deflation illusion, and the tax hypothesis.

\section{Availability Heuristics}

Deflation has a bad name among economists and investors. Saying the word deflation and most people picture in their minds the Great Depression in the 1930s and see before them Henry Fonda and Jane Darwell in the Hollywood movie version of John Steinbeck's “Grapes of Wrath". In behavioural finance, the availability heuristic may lead to predictable decision biases if the decision maker focuses on much of the (emotional) strength of the data and less on more rational data, such as frequency and probability (Tversky \& Kahnemann, 1973). However, in the 1930s, the underlying problem was not (consumer price) deflation, but more likely the preceding burst of the asset bubble on Wall Street and high real interest rates. Note the availability heuristic does not offer an explanation for why stock prices and valuation ratios behave as they do under periods of deflation, but it helps to explain why stock prices and valuation ratios may behave different from what was expected.

\section{Deflation Illusion}

Interestingly, the theoretical exercise suggests a larger drop in $\mathrm{P} / \mathrm{E}$ ratios than what real world $\mathrm{P} / \mathrm{E}$ ratios and the extrapolation exercise seems to suggest. Either the assumptions in the theoretical examples are too

12 These P/E levels are robust when changing the estimation period from 1979-2016 to 1985-2016. 
harsh, and/or investors might suffer from deflation illusion, a sort of reverse inflation illusion. Recall that investors in the face of (high) inflation are believed to commit two errors: Firstly, failing to discount real cash flows with a nominal discount rate (i.e., basically to forget to adjust next period cash flows properly for inflation), and secondly, failing to recognize that nominal debt decrease in real value in the presence of (high) inflation. The deflation illusion hypothesis is simply a mirror image of the inflation illusion hypothesis, suggesting that investors fail to adjust next period cash flows properly in the face of deflation and fail to adjust upward the real value of nominal debt when inflation is negative.

\begin{tabular}{|l|l|l|l|l|}
\hline \multirow{2}{*}{ Variable } & \multicolumn{2}{|c|}{ Inflation Illusion Situation } & \multicolumn{2}{c|}{ Deflation Illusion Situation } \\
\cline { 2 - 5 } & Investor Behavior & Impact on Stock Prices & Investor Behavior & Impact on Stock Prices \\
\hline Discount Rate & Nominal & None & Nominal & None \\
Cash Flows & Real & Undervaluation & Real & Overvaluation \\
Real Value of Debt & No Adjustments & Undervaluation & No Adjustments & Overvaluation \\
\hline
\end{tabular}

Figure 11. Impact of deflation illusion. Source: Own creation.

The impact of deflation illusion is opposite of that of inflation illusion, suggesting that investors might overvalue stocks in a deflation scenario. The author does not believe that empirical data are sufficient at this point to make a proper empirical test of the hypothesis, which is therefore built on a sand foundation until either rejected or proven not rejected.

\section{Tax Hypothesis}

While the tax hypothesis by Feldstein (1980) goes a long way to explain why share prices suffer during periods of high inflation, exact same argument may be used to explain why share prices do not suffer as expected by some during periods of deflation. Firstly, all other things equal, a firm's cash flow improve as inflation falls (lowers the difference between the cash out investments and the historical depreciation allowances for tax purposes). Secondly, all other things equal, investor's real return after taxes increase as inflation falls. Both of these effects continue to work when low inflation turns into deflation.

\section{Conclusion}

Deflation has a bad name among some economists and most investors. However, from a stock market perspective, deflations' bad name may not be well-deserved. Several observations support this: 1) The 1930s was a statistical outlier and not representative for a deflationary period and deflation does not seem to create recessions, causality goes the other way; 2) real stock returns are positive and around average in the periods leading up to and following the onset of deflation; 3) when moving from low inflation to mild deflation, $\mathrm{P} / \mathrm{E}$ ratios are virtually unchanged; and 4) peak P/E ratios seem to be reached at inflation rates close to zero. The author proposes three possible explanations for the seemingly disconnect between the empirical data and the "default" ex ante belief of most economists and investors: availability heurist, deflation illusion, and tax related issues in connection with the tax hypothesis.

\section{References}

Ahmed, S., \& Cardinale, M. (2005). Does inflation matter for equity returns? Journal of Asset Management, 6(4), $259-273$. Atkeson, A., \& Kehoe, P. J. (2004). Deflation and depression: Is there an empirical link? NBER Working Paper 10268. Balduzzi, P. (1995). Stock returns, inflation, and the "proxy hypothesis": A new look at the data. Economics Letters, 48(1), $47-53$. Banerjee, R., \&Mehrotra, A. (2018). Deflation expectations. BIS Working Papers No.699, February. 
Beckworth, D. (2007). The postbellum deflation and its lessons for today. The North American Journal of Economics and Finance, $18(2), 195-214$.

Beirne, J., \& Bondt, G. (2008). The equity premium and inflation. Applied Financial Economics Letters, 4, 439-442.

Benhabib, J., \& Spiegel, M. M. (2009). Moderate inflation and the deflation-depression link. Journal of Money, Credit and Banking, 41(4), 787-798.

Bernanke, B. S. (2002). Deflation: Making sure "it" dosen't happen here. The Federal Reserve Board, Speech before the National Economist Club, November 21, Washington D.C.

Bernstein, W. J., \& Arnott, R. D. (2003). Earnings growth: The two percent dilution. Financial Analyst Journal, 59(5), 47-55.

Bhamra, H. S., Dorion, C., Jeanneret, A., \& Weber, M. (2017). Deflation, sticky leverage and asset prices. Working Paper, February 13. Retrieved from http://www.ssrn.com

Blanchard, O. J. (1993). Movements in the equity premium. Brookings Papers on Economic Activity, (2), 75-138.

Bohl, M. T., \& Siklos, P. L. (2004). The stock market and the business cycle in periods of deflation, (hyper-) inflation, and political turmoil: Germany, 1913-1926. In C. Richard, K. Burdekin, and P. L. Siklos (Eds.), Deflation. Cambridge: Cambridge University Press.

Bordo, M. D., Lane, J. L., \& Redish, A. (2004). Good versus bad deflation: Lessons from the gold standard era. NBER Working Paper 10329.

Borio, C., Erdem, M., Filardo, A., \& Hofmann, B. (2015). The costs of deflations: A historical perspective. BIS Quarterly Review, March, 31-54.

Brandt, M. W., \& Wang, K. Q. (2003). Time-varying risk aversion and unexpected inflation. Journal of Monetary Economics, 50(7), 1457-1498.

Brown, W. O., Huang, D., \& Wang, F. (2016). Inflation illusion and stock returns. Journal of Empirical Finance, 35, $14-24$.

Buraschi, A., \& Jiltsov, A. (2005). Inflation risk premia and the expectations hypothesis. Journal of Financial Economics, 75(2), 429-490.

Campbell, J. Y., \& Toumo, V. (2004). Inflation illusion and stock prices. The American Economic Review, 94(2), 19-23.

Capie, F., \& Wood, G. (2004). Price change, financial stability, and the British economy, 1870-1939. In C. Richard, K. Burdekin, and P. L. Siklos (Eds.), Deflation. Cambridge: Cambridge University Press.

Cohn, R. A., \& Lessard, D. R. (1981). The effect of inflation on stock prices: International evidence. Journal of Finance, 36(2), $277-289$.

Cohen, R. B., Polk, C., \& Vuolteenaho, T. (2005). Money illusion in the stock market: The Modigliani-Cohn hypothesis. The Quarterly Journal of Economics, 120(2), 639-668.

Davies, A. (2004). Credit spread modeling with regime-switching techniques. Journal of Fixed Income, 14, 36-48.

DeLong, J. B. (1999). Should we fear deflation? Brooking Papers on Economic Activity, 1, 225-252.

Eichengreen, B. (2015). Deflation and monetary policy. BOK Working Paper No.2015-25, Bank of Korea.

Fama, E. (1981). Stock returns, real activity, inflation, and money. American Economic Review, 71(4), 545-565.

Fehr, E., \& Tyran, J. R. (2001). Does money illusion matter? American Economic Review, 91(5), 1239-1262.

Feldstein, M. (1980). Inflation and the stock market. American Economic Review, 70(5), 839-847.

Fregert, K., \& Jonung, L. (2004). Deflation dynamics in Sweden: Perceptions, expectations, and adjustments during the deflation of 1921-1923 and 1931-33. In C. Richard, K. Burdekin, and P. L. Siklos (Eds.), Deflation. Cambridge: Cambridge University Press.

Friedman, M. (1969). The optimum quantity of money and other essays. Chicago: Aldine Publishing Company.

Glasner, D. (2011). The Fisher effect under deflationary expectations. Staff Paper, January, Federal Trade Commission.

Groth, C., \& Westaway, P. (2009). Deflation. Bank of England, Quarterly Bulletin, Q1, 37-44.

Guerro, F., \& Parker, E. (2006). Deflation, recession and slowing growth: Finding the empirical link. The IUP Journal of Monetary Economics, 4(1), 37-49.

Hori, M., \& Shimizutani, S. (2005). Price expectations and consumption under deflation: Evidence from Japanese household survey data. International Economics and Economic Policy, 2(2), 127-151.

Kang, J., \& Pflueger, C. E. (2015). Inflation risk in corporate bonds. Journal of Finance, 70(1), 115-162.

Kim, J. R. (2003). The stock return-inflation puzzle and the asymmetric causality in stock returns, inflation and real activity. Discussion Paper 03/03, Deutsche Bundesbank, Economic Research Center.

Kuroda, S., \& Yamamoto, I. (2014). Is downward wage flexibility the primary factor of Japan's prolonged deflation? Asian Economic Policy Review, 9(1), 143-158. 
Kyriacou, K., Madsen, J. B., \& Mase, B. (2006). Does inflation exaggerate the equity risk premium? Journal of Economic Studies, 33(5), 344-356.

Leuthold, S. C. (1981). Interest rates, inflation and deflation. Financial Analyst Journal, 37(1), 28-41.

Madsen, J. B. (2002). The share market book and the recent disinflation in the OECD countries: The tax-effect, the inflation-illusion and the risk-aversion hypothesis reconsidered. The Quarterly Review of Economics and Finance, 42, 115-141.

Madsen, J. B., \& Milas, C. (2005). The price-dividend relationship in inflationary and deflationary regimes. Finance Research Letters, 2(4), 260-269.

Madsen, J. B., \& Dzhumashev, R. (2009). The equity risk premium puzzle and the ex post bias. Applied Financial Economics, 19, 157-174.

Modigliani, F., \& Cohn, R. A. (1979). Inflation, rational valuation and the market. Financial Analyst Journal, 35(2), 24-44.

Morana, C. (2005). The Japanese deflation: Has it had real effects? Could it have been avoided? Applied Economics, 37(12), $1337-1352$.

Motley, B. (1969). Inflation and common stock values: Comment. Journal of Finance, 24(3), 530-535.

Nichols, D. A. (1968). A note on inflation and common stock values. Journal of Finance, 23(4), 655-657.

Nishizaki, K., Sekine T., \& Ueno, Y. (2014). Chronic deflation in Japan. Asian Economic Policy Review, 9(1), 20-39.

Noussair, C. N., Richter, G., \& Tyran, J. R. (2012). Money illusion and nominal inertia in experimental asset markets. Journal of Behavioral Finance, 13(1), 27-37.

Ritter, J. R., \& Warr, R. S. (2002). The decline of inflation and the bull market of 1982-1999. Journal of Financial and Quantitative Analysis, 37(1), 29-61.

Sharpe, S. A. (2002). Reexamining stock valuation and inflation: The implications of analysts' earnings forecasts. Review of Economics and Statistics, 84(4), 632-648.

Smith, G. W. (2006). The spectre of deflation: A review of empirical evidence. Canadian Journal of Economics/Revue canadienne d'Economique, 39(4), 1041-1072.

Summers, L. H. (1981). Inflation and the valuation of corporate equities. NBER Working Paper No. 824, December.

Summers, L. H. (2014). U.S. economic prospects: Secular stagnation, hysteresis, and the zero lower bound. Business Economics, 49(2), 65-73.

Temin, P. (1973). Did monetary forces cause the depression? Working Paper No. 107, Department of Economics, MIT (April).

Thornton, M. (2003). Apoplithorismosphobia. Quarterly Journal of Austrian Economics, 6(4), 5-18.

Tristani, O. (2007). Model misspecification, the equilibrium natural interest rate and the equity premium. Working Paper Series No. 808, September, European Central Bank.

Tversky, A., \& Kahnemann, D. (1973). Availability: A heuristic for judging frequency and probability. Cognitive Psychology, 5, 207-232. 